\title{
Does European History Repeat Itself ? : Lessons from the Latin Monetary Union for the European Monetary Union
}

\author{
Ralf Fendel \\ WHU - Otto Beisheim School of Management, Vallendar, Germany \\ David Maurer \\ Swiss National Bank, Bern, Switzerland
}

\begin{abstract}
Even among academics, it is less known that Europe already witnessed a monetary unification project in the second part of the $19^{\text {th }}$ century. The unification endeavours culminated in the creation of the Latin Monetary Union in 1865, which eventually failed. This paper compares the historical event of the Latin Monetary Union to the current European Monetary Union. More specifically, it searches for differences and similarities between the two monetary unions. We find that even if the specific problems of a monetary union in the $19^{\text {th }}$ century based on a bimetallic standard do not compare to those of a monetary union these days on a more general level, problems are surprisingly alike. In both monetary unions, we observe a lack of enforceable disciplinary measures, inadequate stability criteria, as well as diverging economic and political interests, consequently leading to extensive free-rider behaviour among member states. The
\end{abstract}

\footnotetext{
* Corresponding Author: Ralf Fendel; WHU - Otto Beisheim School of Management, Burgplatz 2, 56179 Vallendar, Germany; Tel: +49 2616509284, Fax:+49 2616509284, E-mail: Ralf.Fendel@whu.edu.

Co-Author: David Maurer; Swiss National Bank, Bundesplatz 1, 3003 Bern, Switzerland; Tel: +41 58630690, E-mail: david.maurer@snb.ch. The views expressed are those of the author and do not necessarily relate to those of the Swiss National Bank.
}

Acknowledgements: The authors would like to express their gratitude to Michael Frenkel, Patrick Lengg, Jürg Mägerle, Jan-Christoph Ruelke, and Andy Sturm for their invaluable comments. 
study of the Latin Monetary Union and its disintegration suggests that a monetary union can only prevail within a strong regulatory and disciplining framework sharing an overarching vision of its members towards establishing a common political union.

JEL classification: N13, E42, F55

Keywords: Latin Monetary Union, European Monetary Union, Monetary Integration

\section{Introduction}

“History doesn't repeat itself, but it does rhyme.” Mark Twain

While the creation of the European Monetary Union (EMU), along with the introduction of the euro, represents a bold venture without precedent in monetary history, it might be less known that Europe experienced similar fervour for monetary unification more than one and a half century ago. This culminated in the creation of the Latin Monetary Union ${ }^{1}$ (LMU) in 1865 consisting of the founding members France, Italy, Belgium, and Switzerland, and later joined by Greece. The Scandinavian Monetary Union (SMU) formed in 1873 by Sweden, Norway, and Denmark is another prominent example. Despite the broad similarities in motivation leading to the creation of monetary unions across time, one crucial point is worth noting from the very beginning when referring to the $19^{\text {th }}$ century: All monetary unions that emerged then were based on a metallic standard. Consequently, the specific problems supporting the endeavour to unify on a monetary basis were different in the 1860s from today. Based on a bimetallic standard, the LMU for example, was exposed to arbitrage forces that caused coins in the overvalued metal to disappear from circulation at all those times when the gold/silver market price ratio deviated from the official gold/silver ratio fixed by the bimetallic standard. However, despite these technical particularities, on a more general level, problems of past and present monetary unions are surprisingly alike.

\footnotetext{
${ }^{1}$ Although it was the name convention monétaire that was used in official documents, the union was thereafter commonly referred to as Latin Monetary Union in relation to the geographical area (and origin of language) of some of its member nations and in contrast to the other European monetary unions of the second part of the $19^{\text {th }}$ century; among the latter are the German Monetary Union (Münzverein) established in 1875 with the creation of the Reichsbank, and the Scandinavian Monetary Union established in 1873 (Einaudi 2001).
} 
Due to the sovereign debt crisis, the EMU has entered stormy waters and quite a few observers even project the possibility of a complete collapse. Politicians, academics, journalists, and many others currently debate about the proper solution to EMU's actual problems. Given the fact that European economies (at least partly) already witnessed a failure of a monetary unification project, this paper aims to contribute to the current discussion from a very different angle. It compares the historical event of the Latin Monetary Union to the current EMU and tackles the question raised in its title. More specifically, it searches for differences and similarities between the two monetary unions.

For this purpose, the paper is structured as follows. Section II provides a sketch of the historical background of monetary and political union in which the LMU was bedded. Subsequently, Section III characterizes the LMU. Section IV confronts the LMU with the EMU and its current problems. Finally, Section V concludes.

\section{The Pre-Latin Monetary Union}

The middle of the $19^{\text {th }}$ century was dominated by a spirit of progress in line with the remarkable strides occurring in technology and science. Table 1 displays estimates of the per capita income as an indicator of economic development of several countries for the year 1870 . 
Table 1. Per capita income estimates for 1870

\begin{tabular}{|c|l|c|}
\hline Rank & \multicolumn{1}{|c|}{ Country } & US Dollars in 1975 \\
\hline 1 & Australia & 1,922 \\
\hline 2 & United Kingdom & 1,214 \\
\hline $\mathbf{3}$ & Belgium & $\mathbf{1 , 1 3 7}$ \\
\hline $\mathbf{4}$ & Switzerland & $\mathbf{1 , 1 1 8}$ \\
\hline 5 & Netherlands & 1,104 \\
\hline 6 & United States & 1,038 \\
\hline 7 & Denmark & 883 \\
\hline 8 & Canada & 881 \\
\hline $\mathbf{9}$ & France & $\mathbf{8 4 7}$ \\
\hline 10 & Austria & $\mathbf{7 5 1}$ \\
\hline $\mathbf{1 1}$ & Italy & $\mathbf{7 4 6}$ \\
\hline 12 & W.Germany & $\mathbf{7 3 1}$ \\
\hline 13 & Norway & 665 \\
\hline 14 & Sweden & 557 \\
\hline 15 & Finland & 506 \\
\hline 16 & Japan & 328 \\
\hline & & \\
\hline
\end{tabular}

(Source) De Long (1988, p. 1,152).

The increasing international trade integration strongly encouraged the quest for international uniformity of weights and measurements, as well as of universal coinage (Bartel 1974). Primarily motivated by the search for monetary stability, as well as closer trade integration, the neighbouring countries Switzerland, Belgium, Italy, and France founded the LMU in the year 1865. Prior to the foundation of the LMU, the French monetary coinage dominated much of Central Europe in the middle of the $19^{\text {th }}$ century.

\footnotetext{
${ }^{2}$ These estimates are based on the countries' boundaries at the time of publication of the cited article (1988). In 1988 Germany, for example, was still separated in West and East. This explains why DeLong (1988) refers to W.Germany. The 1870 territorial reality of some of the countries listed in the table deviates from the one at the time of publication of the cited article. Germany of 1870 , for example, also covered areas belonging to current day Poland.
} 
Monetary systems between those countries that later formed the LMU had already been subject to harmonization tendencies using the French system as their general archetype.

In the European context of those days, France belonged to one of the five great powers in Europe besides Austria, Great Britain, Prussia, and Russia. Together, they formed what became the so called Concert of Europe, a balance of power between the five empires that was expected to be a foundation for peace in Europe. Yet, the hopes in the peace-bringing by Concert of Europe began to gradually erode in the second half of the $19^{\text {th }}$ century as a range of wars broke out between its participants. The common goals of the five powers for stability and peace in Europe were little by little substituted by increasing political and economic ambitions. Compared to France, the other three founding members of the LMU, all neighbours to France, were only of insignificant political importance in Europe and were in fragile domestic conditions. Belgium was a young kingdom that had gained independence from the Kingdom of the Netherlands in 1839 , Italy was for the most of the $19^{\text {th }}$ century in a conflict-ridden process of internal unification towards a united kingdom of Italy and in wars to integrate Italian regions under the rule of foreign powers. Switzerland in turn had become a confederation in 1848 after a period of heavy internal tensions climaxing in a short civil war in 1847.

Without a mutual agreement, Belgium, Switzerland, and the Kingdom of Sardinia ${ }^{3}$ (one of the kingdoms existing in Italy prior to the unification of Italy towards the Kingdom of Italy) had accepted French coins as legal tenders and had taken them as a standard for their own minting. However, Belgian, Italian, and Swiss coins were also mutually used across those countries. Such multilateral interrelated acceptance of other coins and the similarity of the coinage systems created fruitful ground for the union's creation. It was in line with the political interest of France to extend its influence in Europe by means of having its monetary system spread beyond its borders. In order to understand the motivation for and the construction, as well as the challenges of the LMU, a solid understanding of the metallic standard, in particular a French variation of bimetallism is crucial.

\section{A. Bimetallism and its challenges}

Monetary systems in the $19^{\text {th }}$ century were based on precious metals. With the

\footnotetext{
${ }^{3}$ The Kingdom of Sardinia, in turn, was the driving force behind the monetary unification of Italy, which led to the completion of the Italian Monetary Union in 1861 (Fratianni and Spinelli 1985).
} 
unilateral acceptance of the French coinage system, countries automatically adopted the bimetallic standard. The coins in circulation were either made out of gold or silver with a face value corresponding to the value of the metal they were made of. However, the most dominating form was a monometallic standard where only one metal could be legally used for payments without any restriction. Most European countries based their currency on silver, while some on gold. ${ }^{4}$

Only a few European countries had a bimetallic standard, its fiercest advocate being France. Due to France's increasing monetary influence, all countries that unilaterally adjusted their monetary system to that of France took over the bimetallic standard automatically. Bimetallist countries recognised both silver and gold as legal tenders and both metals played an equal role in payment. Silver coins could be used for common daily transactions of a lower value than the smallest gold coins, while gold was generally used for more valuable transactions.

In a bimetallic system, the official relative price of gold to silver was set by law at the mint, called the mint ratio. Most European bimetallic countries in the $19^{\text {th }}$ century defined the mint ratio as 1:15.5, where 1 kilogram of gold was worth 15.5 kilograms of silver. This ratio corresponded to the real market ratio of the two metals around the year 1800. For France, it was in 1803 when the mint ratio was set by law to 1:15.5.

As Figure 1 shows, the actual gold/silver ratio in the market could, however, deviate from the mint ratio, for example in times of new gold or silver findings. In this case, the metal that rose in its market value was undervalued in the bimetallic country due to the fixed mint ratio. Coins made out of this metal were then either hoarded in the bimetallic country or melted and taken abroad where they could be sold at higher market prices than at the mint. As a consequence of a fluctuating market ratio, bimetallism turned out to be an alternating standard and was therefore considered an unstable regime. In essence, the challenges intrinsic to bimetallism are known as the Gresham's Law, popularly understood as bad money drives out good money.

\footnotetext{
${ }^{4}$ Great Britain, as one of the major economic and political powers of those days had officially introduced the gold standard in 1816 , although this standard had already been practised there for more than a century.
} 


\section{Figure 1. Gold / Silver market ratio}

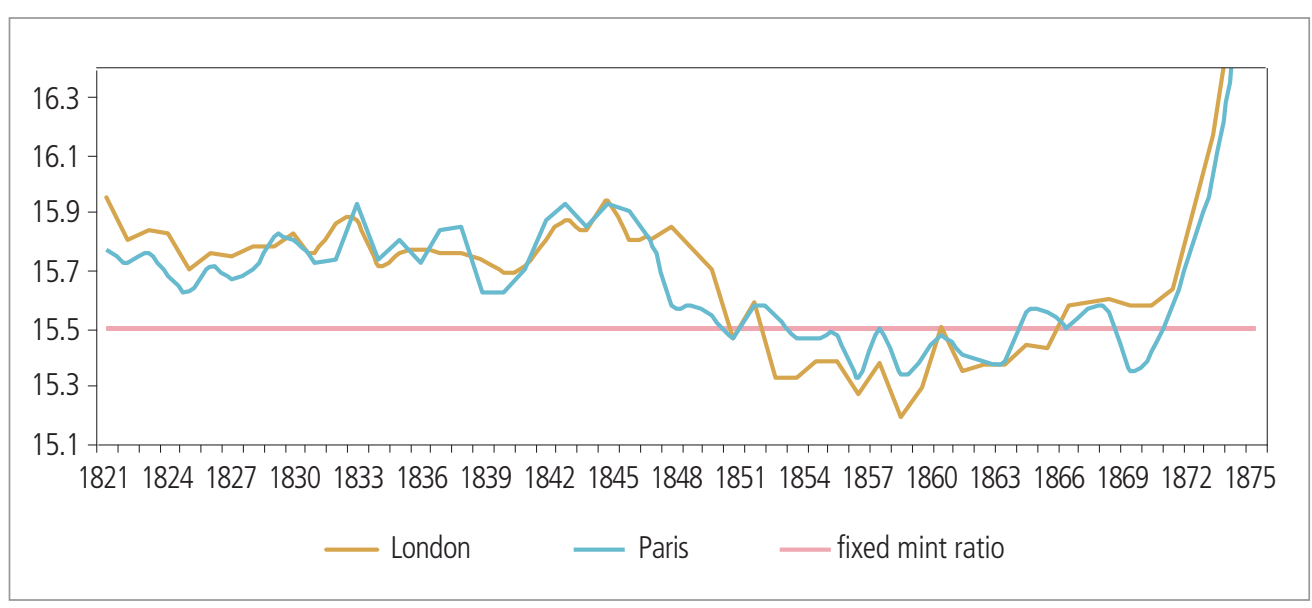

(Source) Flandreau (1995a, p. 340 341).

Soon after the mint ratio was fixed in 1803, arbitrage forces unfolded. The price of gold increased slightly and silver drove out gold. Eventually, only silver circulated in France and gold remained for exclusive transactions (Redish 1994). Consequently, despite its official bimetallic standard, France experienced de facto a time of silver monometallism. This unfavourable situation caused the French government to contemplate a move towards a silver standard. However, it refused such a plan, alluding to the inconvenience to perform expensive transactions with high silver volumes (Redish 1994). Replaced from regular use and only serving select circumstances, gold became known as the pocket money of the rich in France (Eichengreen 2000).

The situation changed dramatically for all de facto bimetallic countries when in 1848 and again in 1851, major gold strikes occurred in California and Australia and consequently market prices of gold decreased. As a direct consequence, devalued gold was increasingly shipped to France where the mint bought it at the guaranteed ratio, which in turn caused a major outflow of silver (Eichengreen 2000). The bimetallic system gradually became more unstable and caused arbitrage costs, as well as major turmoil in the economies. Governments approached this problem by issuing token coins with a silver content that was below arbitrage incentive to provide a small-denomination medium of exchange (Redish 1994). ${ }^{5}$

\footnotetext{
${ }^{5}$ Alternatively, the mint equivalent of silver (gold) could be changed. However, according to Redish (1994), altering the mint ratio was not popular.
} 
It was the Swiss government in 1860 that acted first and lowered the $90 \%$ silver content (as it was the French standard) of all coins smaller than two francs to $80 \%$ silver content, while leaving their weight and appearance unchanged. Italy followed suit soon after (Chown 2003). On the other hand, France believed that the contemporary shortage of silver coins was only temporary and it initially refused to introduce tokens. Eventually, France reduced the silver content of only their 20 and 50 centimes coins from $90 \%$ to $83.5 \%$. Because the Swiss and the French currencies were jointly circulating in both countries even before the LMU's creation, the situation of token coins with a different fineness of silver created another major source for arbitrage. Soon, the uncoordinated token coinage led to a situation where France and Belgium, which had not lowered the silver content of any of their coins, were both invaded by debased silver coins from Switzerland and Italy. On the one hand, Switzerland and Italy gained considerable seignorage ${ }^{6}$ profit by issuing coins with a silver content less than their face value, particularly since they were also used in other countries (Chown 2003). Belgium and France were almost entirely deprived of their own small coins so that at one point, the French treasury prohibited its public offices to accept Swiss tokens (Fould 1864, as cited in Redish 1994, p. 83).

The preceding description shows that compared with our current time of fiat money, the specific problems supporting in the Latin Monetary Union (LMU) in the 1860s were crucially different. It is in this historical context when the foundation of the LMU among France, Belgium, Italy, and Switzerland took place in Paris in 1865.

\section{B. Motivation for the creation of the Latin Monetary Union}

The problematic monetary developments in countries on a bimetallic standard in the second half of the $19^{\text {th }}$ century emphasised the urgency for some sort of coordination. Moreover, besides this immediate necessity, there was a wide range of other reasons for countries to join the LMU. Most of them found their reflection in the strand of literature, known as the Theory of Optimum Currency Areas which entered the academic discourse only a century later. Despite the significantly different monetary reality of those days, there were in fact astounding similarities in the motives for a monetary union compared to those of modern days.

\footnotetext{
${ }^{6}$ Seignorage in this context refers to the divergence between a coin's face value and the value of the silver contained in it expressed in gold (Vanthoor 1996).
} 
The call for coordination of token issuance was in fact nothing but the call for the benefits resulting from a common unit of account. Willis (1901, p. 40) notes, for example, that circulation was impeded, and the ancient and precious uniformity so long enjoyed by Belgium, France, and Switzerland had vanished. Frontier trade was impeded, and travellers were subject to inconvenience. Since the members of the LMU already used the French system before its creation, having a unit of account in this context refers to a coordinated fineness of silver in token coins.

Furthermore, LMU member states expected an increase in competition and price transparency through monetary coordination. As the $19^{\text {th }}$ century was dominated by varying forms of units of weight, length, and volume, providing similar money was at least a first step towards harmonization (Einaudi 2001). ${ }^{7}$

Another major motivational reason for countries to join the LMU was simply to obtain access to capital. Paris was one of the major financial capitals of that time and played an important role in providing capital to its neighbours. Countries attempted to tie themselves to the French market. By denominating their bonds in the currency of their lenders (French Francs), the borrowers increased the appeal and legibility of their financial commitments (Flandreau 2000). This partially explains why the LMU member countries had unilaterally adopted the French monetary system already beforehand (Flandreau 1995b). Members improved their credibility for lenders even more so by signing the LMU treaty.

At least for part of the member states, the possible import of credibility could also be seen as a big motivator. While the reasons for the initial lack of a country's credibility might be different i.e., fiscal overspending/high inflation rates in modern times, peripheral country with dubious coins in those days, the effects are the same. It is adherence to a common standard that bestows the needed credibility i.e., common currency in modern times, or common treaty in those days.

Furthermore, in his analysis of international trade at the end of the $19^{\text {th }}$ century, Flandreau (1995b) finds that despite a general tendency towards openness, a large part of European trade occurred between neighbouring regions, so that forces of proximity had supported the creation of the LMU. He suggests interpreting the 1865 Convention as a natural regrouping, in the sense that it institutionalised an integration that had initially taken place without any government intervention. Figure 2 shows trade figures among

\footnotetext{
However, it should not be forgotten that there was also opposition to monetary harmonization, particularly among private bankers and (generally non-independent) national banks that benefited most from volatile exchange rates (Einaudi 2001, p. 85 86).
} 
LMU countries before and during the LMU. ${ }^{8}$

Figure 2. Intra Latin Monetary Union trade

A. Exports plus imports

(in million franc)

\begin{tabular}{|l|r|r|r|}
\hline Year & 1860 & 1870 & 1880 \\
\hline Total from LMU & 7443 & 10880 & 14850 \\
\hline Within the LMU & 2202 & 3478 & 3886 \\
\hline \% of Total Trade within LMU & $\mathbf{2 9 . 6 \%}$ & $\mathbf{3 2 . 0 \%}$ & $\mathbf{2 6 . 2 \%}$ \\
\hline
\end{tabular}

B. Percentage of total trade within LMU

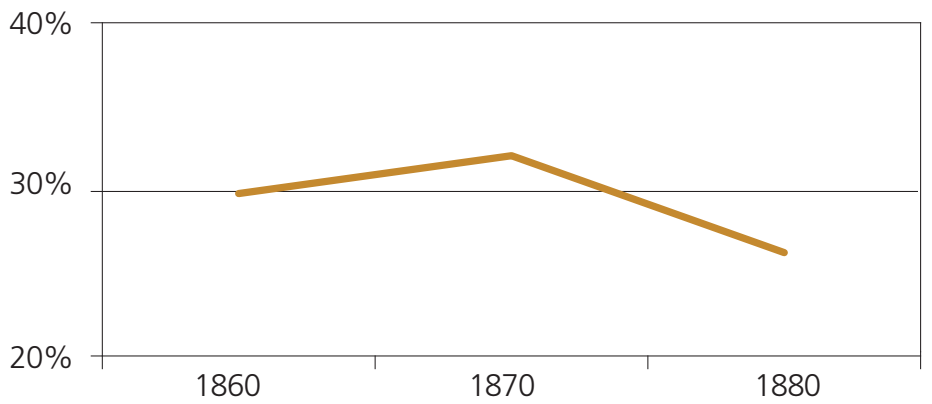

(Source) Adapted from Flandreau (1995b).

Other reasons for LMU accession can be considered to be particular to the unique historical context and only distantly related to the current day experience. For example, Einaudi (2000) mentions that especially small countries appreciated LMU membership for reasons of adequate coinage supply as they were plagued by old and clipped tokens. By letting foreign coins circulate and by ascribing them legal tender status, a country could dispose of its own minting expenses. This is a phenomenon which Theurl (1992) elegantly calls Münzparasitisums (coinage parasitism).

France carried additional individual incentives and vested interest for the foundation

\footnotetext{
${ }^{8}$ The figures indicate an increase in trade in the first few successful years of the LMU and a decrease in intra LMU trade activity in the union's subsequent challenging years.
} 
of the LMU. Due to its dominant position, the creation of the LMU was also intended to serve France's interests on a broader monetary and political scale. For France, the LMU was intended as a springboard to a more comprehensive monetary unification on a global scale based on the French bimetallic standard system. ${ }^{9}$ Weisskopf (1948) perceives the expansion of the French monetary system as one of the necessary means to fortify France's position in the world. This expansion not only occurred via the spread of its coinage system as such, but also by giving other member states access to capital and thereby increasing its economic and political influence on member countries (Flandreau 2000).

\section{The Rise and the Fall of the Latin Monetary Union}

\section{A. Main elements of the Latin Monetary Union treaty}

The treaty of the LMU was signed on $23^{\text {rd }}$ December 1865 by France, Belgium, Italy, and Switzerland. It was initially valid for fifteen years, and was to be extended automatically at fifteen-year intervals. The preamble outlined that the treaty was first of all intended to establish a monetary union with standardized coinage. Thus, the treaty was in principle legitimizing the status quo - mutually circulating coins - and providing harmonization with respect to some problematic minting issues that led up to its creation. Accordingly, the member countries agreed on minting only identical coins that would be mutually accepted by their treasuries. However, unlike the current day EMU, the LMU was not based on a single currency denomination. ${ }^{10}$ The LMU approach was one within which each member country could retain its own denomination at the officially established par value and at the determined size, diameter, and metal content.

Member countries did not have to abolish the name or the imprint of their national monetary symbol: Italy kept the lira, and Belgium, Switzerland, and France their individual franc coins at a par value of 1:1. Furthermore, the treaty did not provide any

\footnotetext{
${ }^{9}$ Already at the LMU founding conference in 1865, De Parieu, France's vice-president, expressed the French government's true intentions behind the monetary unification. He desired to extend the LMU to consider a more distant and larger perspective- that of a uniform monetary circulation for all of Europe (Einaudi 2000, p. 286).

${ }^{10}$ This was different in the Scandinavian Monetary Union where the national currencies were replaced by the Scandinavian krona.
} 
restriction on the minting of gold coins (100 francs, 50 francs, 20 francs, 10 francs, and 5 francs) or silver five franc coins, but countries were required to communicate the quantity of their coin issuance on an annual basis. In reaction to the problematic arbitrage situation with token coins in the forerunning to the LMU, the member states agreed on a uniform silver content of $83.5 \%$ fineness for 2 franc coins and smaller, while Switzerland was granted twelve years to adjust the silver content of its $80 \%$ tokens accordingly.

In order to once and for all prevent countries from the unrestrained minting of tokens with a higher face value than their intrinsic value, the LMU treaty included limiting provisions. The coining of such tokens was restricted on the basis of a country's population to a maximum of 6 francs per capita. Tokens would only serve as legal tender in payments up to a value of 50 francs in private transactions, while treasuries would accept up to a hundred francs of foreign state tokens. Moreover, the treaty stipulated that admission to the LMU was decided by a unanimous vote of the current member states and free to any country that is willing to abide by the rules laid out in the treaty.

Given the substantive arbitrage issues of a bimetallic standard that led to the creation of the LMU, it comes as a surprise that the treaty did not explicitly lay down a clear parity between gold and silver. Implicitly, the treaty was following the customary ratio of 1:15.5. The fact that the treaty contained provisions for both 5 franc silver coins, as well as 5 franc gold coins, clearly displayed the intention not to demonetize silver and to adhere to a bimetallic standard, although the treaty did not include an official statement on this major issue. The status quo of bimetallism continued to be the standard but soon turned out to be a major stumbling block during the existence of the union.

Despite its provisions for harmonization, the treaty also had its faults. It lacked clear agreements on the treatment of worn-out coins, terms on the cooperation of central banks (or issuing institutions), as well as rules regarding the application of discount policy and the use of paper money in the union, the latter of which became a serious issue in the years following the creation of the LMU. ${ }^{11}$

\section{B. The Latin Monetary Union's formal and informal enlargements}

The LMU was enlarged in 1867 by accepting Greece as a new member, an expansion that was in line with France's underlying motivation for universal money. The accession

\footnotetext{
${ }^{11}$ See Jenkis (1969), Vanthoor (1996), Halbeisen, and Müller (1998) for this particular issue.
} 
was subject to the condition that all Greek drachmae coins were to be minted in France. At that time, Greece was a country not to be trusted to abide by the rules (Einaudi 2001) and coeval commentators argued against its accession. Willis (1901, p. 81) for example notes that "it is hard to see why the admission of Greece to the Latin Union should have been desired or allowed by that body ... Economically unsound, convulsed by political struggles, and financially rotten, Greece's condition was pitiable." Eventually, the LMU's expansion to include Greece turned out to be a failure and seemed to merely reflect the handwriting of French hegemonic expansionary interests.

The inclusion of Greece was the only formal enlargement of the LMU. Subsequently, the LMU members were opposed to enlarging the union further. Some other European countries such as Spain and Rumania, however, adhered to the rules of the LMU without being formally a member of it. As stated before, the French interest was to transform the LMU into a truly European or even a global monetary union and this was openly proposed by France from the very beginning. The two main European recipients of this proposal, Germany and Great Britain, did not signal any interest (Einaudi 2000). ${ }^{12}$ Vanthoor (1996), therefore, summarizes that the French plan to transform the LMU into a truly global monetary union had failed.

\section{Achievements of the Latin Monetary Union}

While the flaws in the LMU treaty led to some problematic developments in the course of the union's existence, some well known commentators of the time evaluated the LMU surprisingly positive and praised it as bearing revolutionary character in terms of monetary history. For example, Walter Bagehot (1866) writes:

"The treaty by which the four nations ... bind themselves to use exclusively an identical coinage is one of the most characteristic treatises of the $19^{\text {th }}$ century. In medieval times, governments rather liked their money to be different from other moneys. The right to coining money was an exclusive and half mystic prerogative, and it would have been thought a sacrifice of independence and a commencement of degradation to borrow the coinage of a foreign neighbour." (Bagehot 1866, p. 1,077 cited in Perlman

\footnotetext{
${ }^{12}$ In fact, according to Einaudi (2000), the name Latin Monetary Union (LMU) was coined by the British press to actually stress the impossibility of its extension to Northern Europe. The British Times wrote on September 8, 1866 (p. 8): We may reasonably expect in time to see a complete uniformity in weights, measures, and currency throughout the whole of what, after the Emperor Napoleon, we may call «the Latin races» of the Continent. (Einaudi 2000, footnote 2).
} 
1993, p. 318)

In modern times, however, only a very few scholars view the LMU as a success. By those few, the LMU gets praised for surviving several crises, wars, and political problems; the LMU is seen as a union with constant success since it lasted longer than the international gold standard (De Cecco 1992). ${ }^{13}$ Dealing with token coins is mentioned as another success of the LMU. The face value of token coins was higher than their metal value, hence these tokens can be perceived as a primal form of fiat money since part of their value was not backed by any metal. In light of this, Redish (1994) stresses that the LMU reached one major goal: it succeeded in teaching legislators how to apply token coins in a metal-based system and how to coordinate their use. This coordination turned out to be the raison d'être of the union (p. 82, italics as in the original). Thus, at least in its beginning stages, the LMU became the first monetary union to successfully coordinate the use of tokens across borders. However, these achievements seem to be pushed to the margins of insignificance in the light of the significant problems that the LMU faced due to the lack of adequate compliance provisions, its decentralized monetary policy, and the adherence to bimetallism.

\section{Disintegrating forces in the Latin Monetary Union}

Compared to the stabilization criteria of the current EMU, the ones included in the LMU treaty were rudimentary. It was believed that only two stipulations were sufficient to guarantee stability and compliance with the treaty: First, the requirements for information on the number of coined silver and gold coins and second, the implementation of a carefully monitored coinage limit for tokens. However, these provisions soon proved inadequate in the face of the emerging economic challenges. Flandreau (1993, P.501) finds that as such the LMU was a privileged hunting ground for free-rider problems. ${ }^{14}$ The absence of some appropriate requirements on how to deal with a changing economic environment, proved to become a major stumbling block for the union. Overall, the LMU treaty failed to provide appropriate measures mainly for the following three aspects under which, in turn, the forces can be subsumed as contributing

\footnotetext{
${ }^{13}$ As will be argued later, the LMU's long durability must be attributed to high exit barriers in the form of a liquidation clause and to a lesser extent to its success.

${ }^{14}$ Flandreau (2000), for example, mentions that the LMU failed to provide strong retaliatory measures against countries that might over-issue its coinage.
} 
to the eventual disintegration of the union: bimetallism, the appearance of paper money, and a decentralized monetary policy.

\section{Bimetallism}

The LMU treaty provided at least some coordination solutions for the acute problems that the member states were suffering from. However, the main destabilizing issue, bimetallism, was not resolved and continued to be a sting in the flesh of the union. The LMU fulfilled its objectives merely during a very brief initial period of stability when the price of the two metals remained relatively stable. Shortly after the LMU's creation, the price of silver fell, ${ }^{15}$ which again unleashed the arbitrage forces of Gresham's Law. This meant that due to the fall in the price of silver, it could be exchanged in the LMU countries at an advantageous mint ratio. Thus, silver from around the world was brought to the LMU countries to be exchanged for gold, which in turn led to an outflow of gold from the LMU. Furthermore, these forces of arbitrage did not even prevent members of the LMU from outwitting each other for their individual gain. Eltis (2000) describes that the nations in the union competed to over-issue 5 franc silver coins in an effort to acquire purchasing power from each other.

This shows that bimetallism had taken on an even further perverted form where individual members attacked each other, a situation that obviously could not be maintained for long. As a consequence of such strain, there was an interim period in which the Banque de France became reluctant to accept Belgian and Italian coins, a measure that was diametrically opposed to the unions' fundamental provisions for mutual coinage circulation (Perlman 1993). The situation worsened so that, eventually, the decline in the value of silver relative to gold brought the LMU member countries to suspend the free coinage of silver coins. In 1878, the 5 franc silver coins were no longer minted in any LMU member country.

\section{Paper money}

The decline of the silver price, however, was not the only development with drastic consequences for the LMU. Facing chronic government deficits, Italy began to

\footnotetext{
${ }^{15}$ The fall in the price of silver was caused by four major reasons (Bartel 1974): (i) the demonetization of silver by major global trading countries (i.e., Germany chose gold after the French-German war in 1870 1871); (ii) the increasing use of paper money and tokens instead of silver; (iii) the growing commercial preference for gold over silver; and (iv) increased silver production. According to Kindleberger (1984), another cause for the increase of silver circulating in the market can be attributed to the development of a new electrolytic refinement method for silver, which enabled the processing of low-grade ores and even the tailings of old-mines.
} 
exceedingly issue paper money in the years following the LMU creation as can be seen in Table 2.

\section{Table 2. Growth of bank note circulation in Latin Monetary Union countries}

(average annual growth in percent)

\begin{tabular}{|c|c|c|c|c|}
\hline Time period & France & Belgium & Italy & Switzerland \\
\hline $1865 \sim 1869$ & 12.30 & 11.84 & 100.43 & 1.57 \\
\hline $1870 \sim 1874$ & 13.64 & 12.41 & 12.12 & 46.64 \\
\hline $1875 \sim 1879$ & -2.13 & -0.29 & 1.42 & 1.53 \\
\hline $1880 \sim 1884$ & 5.41 & 1.06 & -2.12 & 4.30 \\
\hline $1885 \sim 1889$ & 0.21 & 1.91 & 0.26 & 2.90 \\
\hline $1890 \sim 1894$ & 2.72 & 3.21 & 2.03 & 1.28 \\
\hline $1895 \sim 1899$ & 1.66 & 4.74 & 0.99 & 3.68 \\
\hline $1900 \sim 1904$ & 1.23 & 1.96 & 1.50 & 0.62 \\
\hline $1905 \sim 1909$ & 3.05 & 3.34 & 5.58 & 3.59 \\
\hline $1910 \sim 1914$ & 8.18 & 15.67 & 9.10 & 10.68 \\
\hline $1915 \sim 1919$ & 36.59 & 52.52 & 54.51 & 24.51 \\
\hline
\end{tabular}

(Sources) Adapted from Mitchell (1998, p. 785 788) for France, Belgium and Italy (as of 1880); adapted from Willis (1901, p. 68) for Italy before 1880; adapted from Ritzmann-Blickenstorfer (1996, p. 804 805) for Switzerland.

At least since the First World War, other LMU countries began to finance wardriven debt by issuing paper money. The increase of money supply by means of printing paper money brought inflation into the system (Bordo and Jonung 2000) as displayed in Table 3. The union, which only provided limits for coinage issuance, was not equipped for such a situation. There was clearly a lack of a precise provision on how to deal with bank notes. Consequently, the Italian lira was the first currency that underwent significant depreciation in its free market value. It paid off for the Italian government to free ride at the expense of other members by using lira tokens to redeem its foreign debt. These tokens continued to have legal tender status in the union countries at a 1:1 par value, a value much higher than the lira's actual market value. Furthermore, the Italian government agreed only to redeem repatriated tokens in their devalued paper currency 
(Redish 1994).

Table 3. Inflation rates in the Latin Monetary Union countries

(average annual growth rates of consumer price indices in percent)

\begin{tabular}{|c|c|c|c|c|}
\hline Time Period & France & Belgium & Italy & Switzerland \\
\hline $1860 \sim 1864$ & 0.47 & -0.61 & -1.24 & 0.74 \\
\hline $1865 \sim 1869$ & 0.00 & 0.59 & 1.56 & -1.39 \\
\hline $1870 \sim 1874$ & 0.65 & 1.72 & 5.36 & 3.28 \\
\hline $1875 \sim 1879$ & 0.22 & -0.38 & 0.99 & -1.50 \\
\hline $1880 \sim 1884$ & 0.21 & -1.46 & -2.63 & -3.95 \\
\hline $1885 \sim 1889$ & -0.22 & -0.45 & 0.45 & 0.75 \\
\hline $1890 \sim 1894$ & 0.00 & -1.84 & -0.65 & -0.36 \\
\hline $1895 \sim 1899$ & -0.22 & -0.25 & -0.22 & 0.27 \\
\hline $1900 \sim 1904$ & -0.22 & -2.60 & 0.68 & 0.33 \\
\hline $1905 \sim 1909$ & 0.66 & 2.38 & 0.55 & 1.76 \\
\hline $1910 \sim 1914$ & 1.25 & 2.11 & 0.73 & 0.93 \\
\hline $1915 \sim 1919$ & 17.08 & n/a & 20.11 & 15.35 \\
\hline
\end{tabular}

(Sources) Adapted from Mitchell (1998, p. 863 865) for France, Belgium and Italy; and adapted from RitzmannBlickenstorfer (1996, p. 502) for Switzerland.

The lack of provisions against free riding significantly contributed to destabilizing the foundations of the union. At the time of the LMU's creation, before the fall in silver price and the beginning popularity of bank note printing, however, the danger for free riding was not imminent, meaning clear free-riding provisions might have been omitted unintentionally. Flandreau (1993) supposes that member countries only comprehended the mutual interdependence of the treaty they signed when the fall of silver price along with the printing of money stimulated free-riding behaviour and threatened the LMU to become out of control.

\section{Decentralized monetary policy}

For such free riding behaviour from a bank note issuance to occur in the first place, 
individual member countries have had to remain monetarily autonomous. De Cecco (1984, p. 46) concludes: The Italian monetary difficulties demonstrated the union's basic shortcomings: it was supposed to unify several national monetary systems but each country went on choosing the course it preferred in economic policy, without any attempt at harmonisation. Many of the challenges that the LMU went through can be directly attributed to its decentralization (Cohen 2001, Graboyes 1990). The voluntariness of participation along with the absence of coercion created a liberty that was one of the most important stumbling blocks of the project of monetary unification. As a matter of fact, this lack of direct means to control the behaviour of free riders led to growing resistance within the French government to the LMU's further expansion (Flandreau 2000). Consequently, the LMU experience clearly exhibits the challenges of a monetary union failing to centralize its monetary policy.

Interestingly, however, after considerable damage had already been done, countries succeeded in applying a measure to confine the incentive for free-riding behaviour shortly before the situation got out of control. The resistance by the Banque de France to accept coins issued in excessive amounts by a foreign government threatened that inflationary countries would be forced to re-import almost all the inflation that they had previously exported (Flandreau 1993). This action provided some interim stability until the restriction of silver coin minting was ruled. Nevertheless, if similar stipulations had already been introduced into the LMU treaty before it was signed, much of the frictions might have been prevented.

\section{E. The creeping end of the Latin Monetary Union}

Because of the considerable challenges arising from the bimetallic standard, Switzerland began to voice its preference to abandon bimetallism in favour of a complete gold standard (Chown 2003). However, the French continued to strongly defend bimetallism. Bankers and financial institutions were the primary beneficiaries of metal arbitrage and, hence, of bimetallism. It is not surprising that the Banque de France, still a private institution at that time, was a strong supporter of bimetallism then because bimetallism provided a continuous source of income (Einaudi 2001). Keeping this in mind, the following dubious argument made by French supporters for bimetallism appeared like mockery. They claimed that silver had to remain in circulation because the French peasantry was used to it and even attached it to the 5 franc silver piece, which 
was easier to handle than the tiny gold coin of equal value (Einaudi 2001).

However, under the continuous challenges caused by bimetallism, the LMU eventually agreed in 1878 to partially abandon bimetallism and to choose what later became known as a limping gold standard (Bordo and Jonung 2000). This meant that the union members did not demonetize all silver coins as would have been the case under a pure gold standard, but only those of 2 francs and 1 franc (Weisskopf 1948). While it was agreed upon to cease the production of new 5 franc silver coins, those 5 franc silver coins that were already in circulation kept their legal tender status (Graboyes 1990).

Faced with the incentives of members to leave the union, France pushed for a liquidation clause. This clause decreed that member countries had to fully redeem in gold any of their outstanding silver coins at their nominal value, in case the country wanted to leave the union (Bae and Bailey 2003). France was holding a massive stock of silver coinage from other countries for which it wanted a guaranteed redemption. For that reason, France introduced this measure as a reaction to Switzerland's explicit pursuit of membership termination by the end of 1885 (Bamberger 1885). Taking into account those possible reimbursement costs, Switzerland had no choice but to withdraw attempts of resignation.

Although the French succeeded in retaining at least a weak, limping form of its bimetallic system, from the year 1878 onwards, the LMU de facto turned into a union of the gold standard and was thus connected via gold with major economic powers. Since bimetallism was causing too many economic problems, the force of economic circumstances was greater than the power of tradition (Perlman 1993). Despite its possible advantages, which current bimetallic theorists have unearthed, the bimetallic standard proved to be a failure in the $19^{\text {th }}$ century and was one of the major stumbling blocks for the LMU.

Nevertheless, the union continued to officially exist for another few decades. What prevented the LMU from disintegrating completely was the fear of possible high exit costs as a consequence of membership resignation or union termination. Due to the fact that the market value of silver was mostly far below its face value, a new agreement was signed stipulating that any party leaving the union would have to exchange the other's holdings of its silver coins into gold (Bordo and Jonung 2000). From the initial spirit of unification among the member states, the only aspect of common interest that remained was avoiding high exit cost. The LMU survived until after World War I. In 1921, a conference of LMU member states was summoned to arrange for its termination and the union officially dissolved when Switzerland declared its resignation in 1926 (Bartel 
1974).

Overall, the LMU suffered from its congenital defects during the entire time of its existence (Jenkis 1969). The coexistence of a global monometallic standard besides a bimetallic standard, however, would inevitably lead to major disturbances for countries on bimetallism. The refrain from demonetising silver coins and the adherence to the bimetallic mint ratio for the case of the outstanding silver coin redemption turned out to be the component that prevented the union's loose strings from falling apart. In the end, it was the gold standard that prevailed. It showed the superiority of monometallism and displayed the surprising reality that a monetary system could be upheld without a decisive treaty. In the end, France's tenacious and questionable defence of bimetallism destroyed both the LMU and France's dream of a French-dominated global monetary system.

\section{European Monetary Union vs. Latin Monetary Union}

By comparing the similarities and differences between the LMU and the EMU, possible lessons might be learned and can be used to guide current decisions. The section starts with the similarities.

Comparing the global economic environment under which the LMU and the EMU were created, many parallels can be observed. Both unions were created in times of increased globalization and deeper regional and global economic integration. The recognition of the national benefits from a more intensive integration with partner countries seems to have been a main driver for monetary unification then and now. The motivation for the creation of the LMU is, to a large extent, also valid for the EMU.

Like the EMU in its initial years, the LMU was perceived as a success story and attracted new member and other applicant countries. After an initial time of blossoming, however, its constructional defects became eminent. The founders of the LMU thought that the formulation of just a few rules was sufficient for providing the long-term stability of the monetary union. This belief, however, turned out to be a fatal mistake. Once an external shock in the form of a drastical fall in the price of silver hit the union, it became evident that the existing rules were insufficient. Although such an event did not come as any surprise because fluctuations in the prices of gold or silver had already been 
witnessed before the LMU, there was no predetermined mechanism to deal with such an event. Furthermore, it turned out to be extremely difficult to agree on a key strategy in the moment of the crisis as many conflicts of interest arose. Vested interests did not only emerge between nations but also between different economic players such as private banks and politicians. This situation remarkably resembles the current situation within the EMU.

The lack of explicit rules in the LMU gave rise to free-riding behaviour. This was exemplified by the lack of rules on how to deal with the issuance of paper money. Also, the lack of fiscal policy coordination contributed to the free-riding behaviour. In the current EMU, free-rider problems are also present, such as excessive governmental borrowing, hoping to benefit from a low-interest rate environment safeguarded by more stability-oriented partner countries. However, it is not so much the lack of explicit rules that occur but the lack of their application. The Stability and Growth Pact with its provisions on government deficit and debt ratio may serve as a good example. In principle, it contains sufficient sanctions against free riding. However, due to the missing willingness for their application and the lack of an automatism, they have never been applied.

While similarities exist, crucial differences between the LMU and the EMU need to be mentioned. The most prominent is the difference in the monetary standard. This precludes the analysis from comparing both unions and their problems on a highly specific or technical level. However, on a more general level, other differences can also be identified. First of all, unlike the EMU, the LMU was established with a limited time horizon of initially 15 years. Furthermore, monetary policy was far less coordinated in the LMU. Most prominently, it lacked a common central bank as the single institution with the right of currency issuance.

Monetary unions based on a single currency exhibit high exit barriers for participating countries due to the sunk costs arising from joining the union. For a union consisting of loosely linked national currencies, the exit barriers are considerably lower due to lower sunk costs for the participating countries (Cohen 2001). Furthermore, the experience of the LMU highlights that a currency union with monetarily sovereign member states exhibits low sunk costs for participants and functions properly as long as the union is free of any major disturbances.

The dissolution of the LMU had almost no negative economic consequences due to the continuance of national currencies (Bordo and Jonung 1999). This cannot be expected for Europe today, where a monetary separation would cause major economic 
damage to all parties involved. It is hard to imagine how exactly the option of a withdrawal or exclusion of one member country, or even the dissolution of the monetary union as a whole, could be handled in reality without causing major damage to the economy and the political system.

Although it is apparent that the distribution of political influence among members in the EMU is hardly even, this imbalance in the distribution of power is not comparable to that within the LMU where France had a very strong hegemonic position. The presence of an individual country's dominance in a monetary union can turn out to be an impediment if the hegemon's interests considerably diverge from those of other member countries. The LMU would not have failed had France's power been used in different manner. Cohen (2001, p. 192) argues that monetary unions tend to be successful, firstly in "the presence ... of a dominant state willing to use its influence to keep such an arrangement functioning effectively on terms agreeable to all, and if a sense of community and solidarity exists among the member states. He claims that where both are present, they are a sufficient condition for success. Where neither is present, unions erode or fail." The LMU in fact, had a hegemonic leading nation, France, but as outlined above, it primarily used its influence for its own agenda and, continually and ruthlessly, overruled the approaches of other members. It was pressure, not the sense of community, which France used for this purpose. The union would have disintegrated much earlier, if France had not initiated the liquidation clause.

Looking at the history of monetary unions besides the LMU, others offer at least two additional insights. (i) National monetary unions such as the German monetary unions (i.e., both the Münzverein and the Re-unification case) and the American Monetary Union are viable. Multinational monetary unions such as the LMU may be more prone to breaking apart once a major shock hits the economies. ${ }^{17}$ This gives rise to the presumption that only those monetary unions that are combined with a political union are able to outlast severe economic crises. Therefore, a pure application of ex-ante economic criteria (i.e., optimum currency area considerations like symmetry of business cycles and economic structures) when building a monetary union is too shortsighted to guarantee stability because it lacks a political dimension. (ii) Monetary unions consisting of one (benevolent) hegemonic country and its junior partner(s) also seem to be relatively stable and long-lasting. Examples of this kind of constructions are the monetary unions

\footnotetext{
${ }^{16}$ See Section III, subsection E.

${ }^{17}$ See Bordo und Jonung (2000) who originally devalued this argument. They also provided an in-depth discussion of the "Münzverein" and the American Monetary Union.
} 
between Switzerland and Liechtenstein, between Belgium and Luxemburg, as well as the West African CFA-Franc zone.

LMU shows that while a monetary union might function for some time without a political union, it is prone to fail when hit by an external shock that exposes its constructional flaws. The conclusion that a political union is prerequisite for a functioning and sustainable monetary union raises the question on how this may be achieved in the case of the current challenges faced by the EMU. Various possible approaches are debated including transferring power from national levels to the EU level, creating a more centralized union, or moving towards a tighter fiscal union. In any case, the approach chosen to strengthen the political union is evidently not limited to the realm of economic arguments. An interplay between a vision of a realistic path towards a political union and some realistic gradual steps towards more economic integration is needed.

The current crisis in the EMU shamelessly reveals areas of economic policy in which reform steps are most necessary. In the ongoing crisis, a functioning European Banking Union with a supervision authority transferred to the European Central Bank can be perceived as a long overdue reform step. The establishment of the European Stability Mechanism is another such important move. In gradually doing so, supranational European institutions are strengthened and built up. Once markets and citizens become confident that those institutions are contributing to the stability and progress in Europe, they will become widely accepted. Such gradual steps might then together form the transition path and strengthen the political union that provides the foundation for a stable currency union in Europe.

Whereas the transition to a political union takes some extended period of time, some immediate steps are necessary. As soon as possible, the EMU needs to be more credible in the enforcement of the criteria of its Stability and Growth Pact. Reforms should include more disciplinary measures that automatically trigger consequences for those countries that are not in line with the pact's instructions on government spending. All such reforms need to be directed towards reducing free riding behaviour which already displayed a severe problem for the LMU. In addition, a mechanism that provides a voluntary controlled (temporary) leave from EMU for individual countries in exceptional situations would potentially stabilize the monetary union as a whole. The exit cost from the EMU would then be much lower, making exit decisions in times of distress much easier. The LMU experience demonstrated that while high exit costs may keep a monetary union artificially alive but malfunctioning over a protracted period. 


\section{Conclusions}

Studying the European history of monetary unions reveals that Mark Twain was right: History does not repeat itself. The differences between the Latin Monetary Union (LMU) and the European Monetary Union (EMU) surmount the similarities. However, European monetary history rhymes. In both cases, several countries agreed to harmonize their monetary system and reaped the benefits of monetary unification. In the first case, the unification occurred in the context of the reality in the mid- $19^{\text {th }}$ century, among a loose conglomerate of countries with no ambition to politically unite and without a central monetary authority — an arrangement that worked for some years in economically peaceful circumstances but was too frail to withstand economically challenging periods, eventually failing.

The study of the LMU, however, teaches the EMU at least four lessons. (i) Inadequate stability criteria sooner or later tend to lead to existential problems for a monetary union. (ii) A lack of ex-ante formulated disciplining measures in the treaty leads to an extensive free-rider behaviour of individual members which, in turn, creates incentives for a disintegration of the union. (iii) The first and the second problem are further amplified in case of a substantial asymmetry of political and economic interests, as well as by a lack of coordination. (iv) A monetary union can only endure political and economic crises if it has a clear regulatory framework which comprises credible disciplining measures. It seems that the current EMU suffers from the very same general deficiencies that are commonly attributed to the LMU: the lack of a clear regulatory framework and the missing incentives and disciplinary measures that ensure stability. If the current EMU is not able to add these to the existing treaty, it will not be viable.

As a consequence, this implies that a monetary union may not work without a political union. At least a common vision to establish a political union needs to be present. In a broader sense, looking at the history of currency unions, it seems that those displaying a strong political will for integration or clearly defined roles of hegemonic and junior partners turned out to be successful and viable. Those that lacked political integration failed. In that sense, European economic history can indeed teach us some lessons. To prevent European monetary history from repeating itself, policymakers should take the event of the current EMU crisis as an urgent imperative to seriously reassess their position towards a political union in Europe. 
To sum up, we present to following policy implications from the European monetary history:

- Binding ex ante stability criteria are a strong necessity for any currency union;

- currency unions provide strong incentives for free riding behavior;

- therefore, disciplining measures need to be formulated and

- these measures need to be enforced at best in a non-discretionary way;

- which might also call for an ordered exit possibility of individual members;

- however, exit costs for individual members and the union as a whole might be higher today than in the LMU;

- crisis situations are manageable by re-adjusting the rules;

- asymmetric political and economic interests always endanger any currency union, thus, a high degree of coordination, at best, a political union is required for the long-term stability;

- thus, the European Monetary Union will only exist in the long run, if there is a much higher degree of coordination with the long-term vision of a true European Political Union. This requires a European identity instead of national interests.

Received 15 February 2013, Revised 14 March 2014, Accepted 18 December 2014

\section{References}

Bae, Kee-Hong, and Warren Bailey. The Latin Monetary Union: Some Evidence on Europe's Failed Common Currency. Ithaca: Cornell University, 2003.

Bagehot, Walter. The Economist, (1077), September 15, 1866.

Bamberger, Ludwig. Die Schicksale des Lateinischen Münzbundes. Berlin: Verlag von Leonhard Simion, 1885.

Bartel, Robert J. "International Monetary Unions: the XIXth Century Experience." Journal of European Economic History 3(3/1974): 689-704.

Bordo, Michael D. and Lars Jonung. Lessons for EMU from the History of Monetary Unions. London: Institute of Economic Affairs, 2000. 
Cohen, Benjamin J. "Beyond EMU: The Problem of Sustainability." In The Political Economy of European Monetary Unification, edited by Barry Eichengreen, and Jeffry A. Frieden, 179-204. Boulder, Colorado: Westview Press, 2001.

Chown, John. A History of Monetary Unions. London: Routledge, 2003.

De Cecco, Marcello. The International Gold Standard - Money and Empire. New York: St. Martin's Press, 1984.

De Cecco, Marcello. "European Monetary and Financial Cooperation before the First World War." Rivista di Storia Economica 9 (1992): 55-76.

De Long, J. Bradford. "Productivity Growth, Convergence, and Welfare: Comment." The American Economic Review 78 (1988): 1138-1154.

Eichengreen, Barry. Vom Goldstandard zum Euro. Berlin: Verlag Klaus Wagenbach, 2000 .

Einaudi, Luca. "From the Franc to the 'Europe': The attempted transformation of the Latin Monetary Union into a European Monetary Union, 1865-1873." Economic History Reviews 53(2/2000): 284-308.

Einaudi, Luca. Money and Politics - European Monetary Unification and the International Gold Standard (1865-1873). Oxford: Oxford University Press, 2001.

Eltis, Walter. "Commentary: Is EMU Sustainable without Political Union". In Lessons for EMU from the History of Monetary Unions. 53-58. London: Institute of Economic Affairs, 2000.

Flandreau, Marc. "On the Inflationary Bias of Common Currencies: The Latin Union Puzzle." European Economic Review 37 (1993): 501-506.

Flandreau, Marc. L'or du monde: la France et la stabilité du système monétaire international 1848-1873. Paris: L'Harmattan, 1995a.

Flandreau, Marc. "Was the Latin Monetary Union a Franc Zone?" In International Systems in Historical Perspective, edited by Jamie Reis, 71-89. London: Macmillan, 1995b.

Flandreau, Marc. "The Economics and Politics of Monetary Unions: a Reassessment of the Latin Monetary Union, 1865-71.” Financial History Review. 7 (2000): 25-43. 
Fould, A. "Origins of the Monetary Union Called Latin - A Report to the Emperor by the Minister of Finance." 1864: Reprinted in the Appendix to Proceedings of the International Monetary Conference of 1878. US Congress House, misc. doc. No 396, $49^{\text {th }}$ Congress, $1^{\text {st }}$ Session (US serial set 2430): 782-786.

Fratianni, M. and F. Spinelli. "Currency Competition, Fiscal Policy and the Money Supply Process in Italy from Unification to World War I" Journal of European Economic History 14(3/1985), 471-499.

Graboyes, Robert F. "The EMU: Forerunners and Durability.” Federal Reserve Bank of Richmond Economic Review 4 (1990): 8-17.

Halbeisen, Patrick and Margrit Müller. "Die schrittweise Nationalisierung des Geldes: Von der Einführung der Schweizer Währung (Münzreform 1848) zur nationalen Kontrolle über das Geldwesen (Gründung der Nationalbank 1907).” In Österreichs Weg zum Euro edited by Alois Mosser, 63-86. Wien: Manzsche Verlagsund Universitätsbuchhandlung, 1998.

Jenkis, Helmut. “Münzunion oder Währungsunion?” Zeitschrift für Nationalökonomie 29 (1969): 121-150.

Kindleberger, Charles. A Financial History of Western Europe. London: George Allen \& Unwin Publishers, 1984.

Maddison, Angus. Phases of Capitalist Development. Oxford: University Press, 1982.

Mitchell, B.R. International Historical Statistics: Europe 1750-1993. London: Macmillan, 1998.

Mundell, Robert, A. "A Theory of Optimum Currency Areas." The American Economic Review 51(4/1961): 657-665

Perlman, Mark. "In Search of Monetary Union." Journal of European Economic History 22(2/1993): 313-332.

Redish, Angela. "The Latin Monetary Union and the Emergence of the International Gold Standard." In Monetary Regimes in Transition, edited by Michael D. Bordo, and Forrest H. Capie, 68-85. Cambridge: Cambridge University Press, 1994.

Ritzmann, Franz. Die Schweizer Banken. Geschichte - Theorie - Statistik. Bern: Verlag Paul Haupt, 1973. 
Theurl, Theresa. Eine gemeinsame Währung für Europa, 12 Lehren aus der Geschichte. Innsbruck: Österreichischer Studien Verlag, 1992.

Vanthoor, Wim F. V. European Monetary Union since 1848. A Political and Historical Analysis. Cheltenham UK: Edward Elgar Publishing Limited, 1996.

Weisskopf, Erich. Das Schweizerische Münzwesen von Seinen Anfängen bis zur Gegenwart. Bern: Buchdruckerei Werder, 1948.

Willis, Henry P. A History of the Latin Monetary Union. Chicago: University of Chicago Press, 1901. 